\title{
Mekanisme Pasar dan Penetapan Harga Dalam Perekonomian Islam (Studi Analisis Pemikiran Ibn Taimiyah)
}

\author{
${ }^{1 *}$ Kendro Pratomo, ${ }^{2}$ Trisna Taufik \\ ${ }^{1,2}$ Fakultas Sains dan Teknologi, Universitas Negeri Sunan Gunung Djati Bandung, Indonesia \\ *Email korenpondensi: jenrya29@gmail.com
}

\begin{abstract}
In the 13th century AD Islamic thinkers emerged in many fields of scientific discipline. Among them appeared Ibn Taimiyah who is an Islamic figure who developed many disciplines in certain fields, each in the field of economics. In his mind many things are related to microeconomics and macroeconomics and the problems that occur at that time. And he founded in terms of social and figh (Islamic) aspects. Ibn Taimiyah did a lot of discussions about care and regulating prices by the government at that time. He also stated that in strong conditions between demand and supply. He also realizes that if the preparation of goods will diminish, it will increasingly affect the price of the item. Therefore, it is very important to see the relationship between price and supply.
\end{abstract}

Keywords: Market Mechanism; Pricing; Demand and supply

Saran sitasi: Pratomo, K., \& Taufik, T. (2018). Mekanisme Pasar dan Penetapan Harga dalam Perekonomian Islam (Studi Analisis Pemikiran Ibn Taimiyah). Jurnal Ilmiah Ekonomi Islam, 4(03), 213-216. doi:http://dx.doi.org/10.29040/jiei.v4i03.331

DOI: http://dx.doi.org/10.29040/jiei.v4i03.331

\section{Pendahuluan}

Pasar merupakan tempat dimana terjadi pertukaran jasa maupun barang yang sudah terjadi secara alamiah sejak awal peradaban manusia. Dalam Islam, pasar ditempatkan dalam kedudukan yang penting untuk menunjang kebutuhan perekonomian yang dilakukan oleh manusia. Sebagaimana pada masa Rasulullah pasar memiliki peranan yang penting dalam membangun peradaban masyarakat islam pada masa itu.

Bahasan yang menjadi sentral para tokoh pemikir islam yaitu mekanisme pasar dan segala problematika yang ada. Sebagaimana Rasulullah menganggap mekanisme yang ada dalam pasar merupakan sesuatu yang harus dihormati, termasuk harga yang diberikan oleh pasar merupakan harga yang adil. Beliau juga menolak adanya price intervention, karena jika perubahan harga yang terjadi didalam pasar diakibatkan oleh mekanisme pasar yang wajar, maka tidak ada alasan apapun untuk meolak harga yang telah ditetapkan oleh pasar (Irawan, 2016).

Perubahan harga yang terjadi dalam suatu pasar bukan semata-mata karena adanya ketidakadilan oleh pedagang maupun penjual sebagaimana banyak orang berpikir seperti itu (Karim, 2006). Hal tersebut menunjukkan bahwa suatu harga yang ada merupakan hasil interaksi antara hukum permintaan dan penawaran yang terbentuk karena berbagai faktor yang kompleks (Al Arif, Rianto \& Amalia, 2014).

Pemikir islam seperti Ibn Taimiyah memiliki pandangan bahwa dalam pasar terdapat berbagai macam problematika yang harus dihadapi, mulai dari penetapan harga yang adil serta mekanisme yang terdapat dalam pasar tersebut. Seperti 
halnya yang terjadi pada masa sekarang sekarang ini, saat penetapan harga tidak dipegang oleh pemerintah maka banyak sekali harga barang yang tidak stabil akibat adanya monopoli perdagangan yang terjadi di pasar. Akibatnya banyak masyarakat dari kalangan tertentu yang sulit mendapatkan barang tersebut karena adanya perubahan harga yang tidak stabil. Hal tersebut mengakibatkan kondisi pasar menjadi tidak stabil dan berdampak buruk pada kehidupan sehari-hari.

Ibn Taimiyah mencoba mengurai berbagai problematika tersebut dan mencari solusi yang efektif dengan membawa pemerintah ke dalamnya.Tetapi dalam hal ini pemerintah tidak boleh semena-mena dalam melakukan penetapan harga. Saat terjadi hal tersebut maka akan terjadi reaksi penolakan terhadap pemerintah dan berujung pada demonstrasi. Ibn Taimiyah berharap bila pemerintah masuk ke dalam mekanisme pasar terutama dalam melakukan penetapan harga yang adil, masyarakat pun menjadi lebih sejahtera karena setiap kebutuhannya dapat terpenuhi.

\section{Metode Penelitian}

Penelitian ini merupakan penelitian kepustakaan (library research) dengan pendekatan deskriptif. Yaitu dengan mendeskripsikan atau menjelaskan pemikiran Ibn Taimiyah tentang mekanisme pasar dan penetapan harga. Metode yang digunakan adalah library research, dengan mengambil berbagai referensi yang terkait dengan tema permasalahan. Disamping itu juga membandingkan dengan hasil yang didapat oleh para ahli serta fenomena dan realitas ekonomi yang ada (Parakkasi \& Kamiruddin, 2018).

\section{Hasil dan Pembahasan}

\subsection{Mekanisme Pasar}

Pada jurnal yang dikemukakan oleh M.Arif Hakim, ia menemukan pendapat bahwa Ibn Taimiyah mengemukakan jika penetapan harga yang dilakukan pemerintah dengan cara menghilangkan keuntungan para pedagang akan menyebabkan terjadinya kerusakan harga, penyembunyian barang oleh pedagang, serta rusaknya kesejahteraan masyarakat. Dengan kata lain, kebijakan pemerintah yang demikian dapat menyebabkan hilangnya persediaan barangbarang dari peredaran (Hakim, 2015).

Ulfa Jamilatul Farida mengungkapkan pada jurnalnya, bahwa Ibn Taimiyah secara umum sangat menghargai arti penting harga yang terjadi akibat mekanisme pasar yang bebas. Ia menolak segala campur tangan untuk menekan atau menetapkan harga sehingga mengganggu mekanisme yang bebas (Farida, 2012).

Pendapat yang dikemukakan oleh Ibn Taimiyah bila dimaksudkan pada masa sekarang ini memang sangat diperlukan apalagi saat menentukan harga yang dapat mengalami perubahan harga yang cukup signifikan. Bila harga tersebut tidak ditekan oleh pemerintah maka masyarakat akan kesulitan untuk memenuhi kebutuhannya. Apabila pemerintah juga semenamena saat menekan harga, maka akan terjadi reaksi penolakan oleh para pedagang yang menjual barang tersebut. Reaksi penolakan yang dihadapi oleh pemerintah dapat berupa demonstrasi maupun para pedagang yang enggan dalam menurunkan harga. Hal tersebut akan menggoyahkan mekanisme pasar yang tadinya stabil berubah menjadi tidak stabil. Dalam hal ini, pemerintah memang harus benar-benar adil. Jadi, harus memikirkan semua pelaku pasar. Tidak hanya memikirkan para pembeli barang, tetapi juga para penjualnya.

Ibn Taimiyah memiliki pemikiran yang teliti terhadap penentuan harga dalam suatu pasar bebas atas dasar kekuatan permintaan dan penawaran. Ia mengemukakan pendapatnya bahwa, "Naik dan turunnya harga tidak melulu dipengaruhi oleh kedzaliman orang-orang tertentu. Terkadang, hal tersebut bisa disebabkan oleh kurangnya produksi atau penurunan dari barang yang diminta. Oleh karena itu, apabila permintaan naik dan penawaran turun, maka harga akan naik. Disisi lain apabila persediaan barang meningkat dan permintaannya menurun, maka harga pun akan turun. Kelangkaan atau kelimpahan yang terjadi semata-mata bukan disebabkan oleh adanya tindakan dari orangorang tertentu. Bisa jadi disebabkan oleh sesuatu 
yang didalamnya terdapat kedzaliman maupun yang didalamnya tidak terdapat kedzaliman itu sendiri. Hal ini adalah kuasa Allah yang telah menciptakan keinginan di hati manusia" (Abdullah, 2010)

Dalam perkataan Ibn Taimiyah jelas bahwa masyarakat pada zaman tersebut memiliki pandangan bahwa perubahan suatu harga barang diakibatkan dari kezaliman para pedagang. Menurutnya pandangan tersebut tidak selalu benar. Ia pun menguraikan alasan ekonomi terhadap naik turunnya harga yang terjadi di pasaran. Ia berpendapat bahwa hasrat dalam memiliki sesuatu (barang) memiliki hubungan yang sangat kuat terhadap munculnya permintaan yang tinggi dipasaran. Permintaan ini yang nantinya akan mempengaruhi harga jual yang terjadi di pasaran. Apabila nantinya permintaan memiliki kenaikan yang signifikan tetapi persediaannya terbatas maka harga-harga dipastikan akan naik pula. Begitu juga sebaliknya, jika terjadi permintaan yang menurun tetapi jumlah persediaannya melimpah maka nantinya harga jual dari barang tersebut akan menurun secara drastis.

Adapun Ibn Taimiyah mengidentifikasi beberapa faktor yang nantinya akan mempengaruhi terhadap besar atau kecilnya permintaan maupun penawaran yang nantinya berdampak pada harga pasar yaitu:
a. Intensitas dan besarnya permintaan
b. Kelangkaan atau melimpahnya barang
c. Kondisi kepercayaan
d. Diskonto dari pembayaran tunai

Perlu diketahui bahwa Ibn Taimiyah mendukung kebebasan dalam sistem keluar-masuk pasar. Meskipun begitu ia tetap memperhatikan hal-hal apa saja yang akan berdampak pada mekanisme pasar nantinya. Ia menyokong standarisasi harga dan melarang adanya pemalsuan serta penipuan terhadap produk yang dijual (Karim, 2011). Lebih jauh dari itu, ia mengkritik keras adanya kolusi antara penjual dan pembeli. Karena akan mempengaruhi harga yang ada di pasar. Ibn Taimiyah juga melarang keras adanya monopoli perdagangan yang ada dipasar (Karim, 2011). Dikarenakan nantinya akan berdampak besar pada perubahan harga dalam pasar, seperti halnya suatu harga dapat dikatakan normal tibatiba terjadi perubahan harga yang signifikan dan melambung tinggi.

\subsection{Penetapan Harga}

Dalam jurnal yang ditulis oleh $\mathrm{H}$. Muhammad Birusman Nuryadin, ia mengemukakan pendapat bahwa jika barang yang tersedia di pasar sedikit, sedangkan barang tersebut diperlukan oleh banyak konsumen, maka harga barang tersebut akan naik. Sebaliknya, bila transportasi antar wilayah lancar maka banyak barang impor yang masuk ke pasar dan menyebabkan melimpahnya barang tersebut sehingga mengakibatkan harga barang akan menurun (Nuryadin, 2007). Ungkapan H. Muhammad Birusman Nuryadin ini senda dengan hukum permintaan keynes.

Euis Amalia mengungkapkan pada jurnalnya bahwa, perubahan dalam penawaran digambarkan sebagai peningkatan atau penurunan dalam jumlah barang yang ditawarkan, sedangkan permintaan sangat ditentukan oleh selera dan pendapatan. Bahwa besar kecilnya kenaikan harga tergantung pada besarnya perubahan penawaran dan permintaan (Amalia, 2013).

Ketika Ibn Taimiyah melakukan analisis terhadap implikasi perubahan penawaran dan permintaan terhadap harga, ia tidak memperhatikan pengaruh tingkat harga terhadap tingkat penawaran dan permintaan. Ia mengemukakan bahwa penetapan harga yang dilakukan oleh pemerintah dengan cara menghilangkan keuntungan yang didapat oleh para pedagang akan menyebabkan terjadinya kerusakan harga (Abdullah, 2010). Dengan kata lain, jika pemerintah mengambil tindakan seperti itu akan menyebabkan hilangnya persediaan barangbarang dari peredaran dan semisal barang tersebut beredar di pasaran maka persediannya hanya sedikit. Karena para pedagang sudah dirugikan oleh kebijakan pemerintah dan enggan untuk menjual barang dengan persediaan yang 
lebih banyak. Ia menyadari bahwa persediaan barang yang menipis akan mengakibatkan perubahan harga secara signifikan.

Ibn Taimiyah membagi masalah dua jenis mengenai penetapan harga, yang pertama yaitu penetapan harga yang dilakukan dengan cara tidak adil dan tidak berlandaskan hukum dan yang kedua yaitu penetapan harga secara adil dan berlandaskan hokum (Abdullah, 2010). Munculnya penetapan harga yang tidak adil bisa terjadi akibat dari kenaikan permintaan dan penurunan penawaran. Akibatnya yaitu timbul rasa cemas dalam masyarakat, karena ditakutkan nantinya tidak akan bisa memenuhi kebutuhan sehari-hari.

Menurut Ibn Taimiyah, dalam melakukan suatu penetapan harga sebaiknya melibatkan pemerintah. Karena ditakutkan jika pemerintah tidak bertindak maka para pedagang akan seenaknya dalam melakukan penetapan harga dari suatu barang tanpa memperhatikan penawaran maupun permintaan. Pemerintah juga dalam menetapkan suatu harga harus memperhatikan dari segi penjual supaya tidak ada yang dirugikan antara penjual dengan pembeli. Penetapan tersebut bertujuan supaya para penduduk dapat memenuhi kebutuhan pokoknya dan mejaga kejujuran dalam suatu mekanisme pasar.

\section{Kesimpulan}

Ibn Taimiyah sangat fokus terhadap hal apa saja yang akan mempengaruhi terhadap mekanisme pasar dan penetapan harga. Dan membuat solusi yang efektif terkait problematika yang ada untuk menciptakan suasana pasar yang adil. Dalam upayanya ia juga melibatkan pemerintah untuk menyeimbangkan kondisi pasar terkait mekanisme dan penetapan harga yang ada di pasar. Ia selalu melarang hal apapun yang nantinya akan merusak mekanisme pasar dan penetapan harga, karena dirasa akan merugikan penjual maupun pembeli. Menurutnya pemerintah memiliki peranan yang sangat sentral dalam mengendalikan pasar. Karena nantinya pemerintah harus memiliki keputusan yang bijak dalam menetapkan suatu harga dalam pasar supaya mekanisme yang terjadi didalamnya dapat berjalan dengan lancar.

\section{Ucapan Terimakasih}

Ucapan terimakasih dan penghargaan diberikan kepada Bapak/Ibu/Sdr yang telah membantu penyelesaian tulisan ini.

\section{Daftar Pustaka}

Abdullah, B. (2010). Peradaban Pemikiran Ekonomi Islam. Pustaka Setia.

Amalia, E. (2013). Mekanisme Pasar dan Kebijakan Penetapan Harga Adil dalam Perspektif Ekonomi Islam. Al-Iqtishad: Jurnal Ilmu Ekonomi Syariah, 5(1).

Arif, A., Rianto, M. N., \& Amalia, E. (2010). Teori mikroekonomi: Suatu perbandingan ekonomi Islam dan ekonomi konvensional. Jakarta: Kencana.

Farida, U. J. (2013). Telaah Kritis Pemikiran Ekonomi Islam Terhadap Mekanisme Pasar Dalam Konteks Ekonomi Islam Kekinian. La_Riba, 6(2), 257-270.

Hakim, M. A. (2016). Peran Pemerintah Dalam Mengawasi Mekanisme Pasar dalam Perspektif Islam. IQTISHADIA (Journal of Islamic Economics and Business), 8(1).

Irawan, M. (2016). Mekanisme pasar Islami dalam konteks idealita dan realita (studi analisis pemikiran al-Ghazali dan Ibnu Taimiyah). Jurnal Ekonomi Dan Bisnis Islam (Journal Of Islamic Economics And Business), 1(1), 67-78.

Karim, A. (2011). Ekonomi Mikro Islam. Jakarta: PT Raja Grafindo Persada.

Karim, A. A. (2006). Sejarah pemikiran ekonomi Islam. PT Raja Grafindo Persada.

Nuryadin, B. (2007). Harga dalam Perspektif Islam. Jurnal Ekonomi Islam: Mazahib, 4(1), 86-98.

Parakkasi, I., \& Kamiruddin, K. (2018). Analisis harga dan mekanisme pasar dalam perspektif islam. Laa Maisyir: Jurnal Ekonomi Islam, 5(1), 107-120. 